\title{
Trends of Antibiotic Resistance in Mesophilic and Psychrotrophic Bacterial Populations during Cold Storage of Raw Milk
}

\author{
Patricia Munsch-Alatossava, ${ }^{1}$ Jean-Pierre Gauchi, ${ }^{2}$ \\ Bhawani Chamlagain, ${ }^{1}$ and Tapani Alatossava ${ }^{1}$ \\ ${ }^{1}$ Division of Food Technology, Department of Food and Environmental Sciences, University of Helsinki, 00014 Helsinki, Finland \\ ${ }^{2}$ Unité de Mathématiques et Informatique Appliquées (UR 341), Centre de Jouy en Josas, Institut National de la Recherche \\ Agronomique, Domaine de Vilvert, 78352 Jouy en Josas, France
}

Correspondence should be addressed to Patricia Munsch-Alatossava, patricia.munsch@helsinki.fi

Received 16 November 2011; Accepted 25 December 2011

Academic Editor: J. D. Stopforth

Copyright (c) 2012 Patricia Munsch-Alatossava et al. This is an open access article distributed under the Creative Commons Attribution License, which permits unrestricted use, distribution, and reproduction in any medium, provided the original work is properly cited.

\begin{abstract}
Psychrotrophic bacteria in raw milk are most well known for their spoilage potential and cause significant economic losses in the dairy industry. Despite their ability to produce several exoenzyme types at low temperatures, psychrotrophs that dominate the microflora at the time of spoilage are generally considered benign bacteria. It was recently reported that raw milk-spoiling Gramnegative-psychrotrophs frequently carried antibiotic resistance (AR) features. The present study evaluated AR to four antibiotics (ABs) (gentamicin, ceftazidime, levofloxacin, and trimethoprim-sulfamethoxazole) in mesophilic and psychrotrophic bacterial populations recovered from 18 raw milk samples, after four days storage at $4^{\circ} \mathrm{C}$ or $6^{\circ} \mathrm{C}$. Robust analysis of variance and non parametric statistics (e.g., REGW and NPS) revealed that AR prevalence among psychrotrophs, for milk samples stored at $4^{\circ} \mathrm{C}$, often equalled the initial levels and equalled or increased during the cold storage at $6^{\circ} \mathrm{C}$, depending on the $\mathrm{AB}$. The study performed at $4^{\circ} \mathrm{C}$ with an intermediate sampling point at day 2 suggested that (1) different psychrotrophic communities with varying AR levels dominate over time and (2) that AR (determined from relative amounts) was most prevalent, transiently, after 2-day storage in psychrotrophic or mesophilic populations, most importantly at a stage where total counts were below or around $10^{5} \mathrm{CFU} / \mathrm{mL}$, at levels at which the milk is acceptable for industrial dairy industrial processes.
\end{abstract}

\section{Introduction}

In developed countries, the sanitation of raw milk is monitored by "total" bacterial counts or SPC (standard plate count). The standard for Grade A or 1 raw milk is an SPC value less than $1.0 \times 10^{5} \mathrm{CFU} / \mathrm{mL}$ [1]. Cooling of raw milk to less than $6^{\circ} \mathrm{C}$ (typically 3 to $4^{\circ} \mathrm{C}$ in the farm tank following milking), followed by storage at temperatures below $6^{\circ} \mathrm{C}$ during transportation to the dairy plant, ensures the quality of raw milk. Because milk is a highly suitable growth medium, many bacterial genera have adapted to this cold-temperature environment by producing exoenzymes (such as proteases or lipases) that can withstand the typical heat treatments milk is subjected to, and they consequently cause significant economic loss to the dairy industry [25]. Psychrotrophic bacteria (able to grow at temperatures ranging from $0^{\circ} \mathrm{C}$ to $7^{\circ} \mathrm{C}$ ) [6] are well known for their ability to degrade both raw and processed milk components which may explain why raw milk psychrotrophs are mainly considered for their spoilage features, with some exceptions like the human pathogens Bacillus cereus (toxin-producing strains) [7], or Listeria monocytogenes [8]. Most genera in psychrotrophic communities are Gram-negative [6] and are generally considered to be benign bacteria. Recently, Gram-negative bacteria have come under higher scrutiny worldwide because many genera host species considered as 
human opportunistic pathogens, which may have antibiotic multiresistant-traits, and infections due to those species may eventually be untreatable $[9,10]$.

Antibiotic resistance (AR) is a consequence of antibiotic $(\mathrm{AB})$ use, overuse, and misuse; $\mathrm{AB}$ administered to animals used for food products is an important source of antimicrobial-resistant bacteria that can spread to humans through the food supply [11-14]. The distribution spectrum and magnitude of the AR gene pool in food-borne pathogens is alarming. Recent studies have concluded that large AR gene pools are present in commensal bacteria in many ready-toeat products and implicated food production and processing environments in the evolution and dissemination of $\mathrm{AR}$ $[15,16]$. The demonstration of the presence of transmissible AR genes in the human food chain was earlier made [17]; thus, food can be considered to be a direct source of AR genes that is consumed daily.

Many studies have determined the prevalence of AR among mastitis pathogens $[18,19]$, several compared the $\mathrm{AR}$ of conventional and organic dairy farming practices $[20,21]$, and others have determined the prevalence of AR among Gram-negative enteric bacteria in bulk milk tanks [22], or mastitis milk samples [23]. However, little is known regarding the AR of raw milk-spoiling psychrotrophs. A phenotypic-based study indicated representatives of Pseudomonas, Acinetobacter, and Stenotrophomonas [24], and the 16SrDNA gene sequences confirmed the identity of some isolates categorized in more risky genera (unpublished data). We investigated the AR of some isolates and observed that multiple AR was rather common, and its incidence increased during the cold chain of raw milk storage and transportation: moreover, a constant increase in AR for isolates originating from farms, lorries, or silos was observed for the following ABs: ticarcillin, aztreonam, cefepime, ofloxacin, and trimethoprim-sulfamethoxazole; bacterial isolates from milk stored in silos more frequently exhibited resistance to clavulonic ticarcillin-clavulAnic acid, ceftazidim, imipenem, colistin, gentamicin, and ofloxacin compared with farm isolates; unfortunately this study considered independent samples [25]. To further investigate whether the cold storage of raw milk promotes an increase in AR traits, we evaluated the AR of total mesophilic and psychrotrophic populations of raw milk stored at 4 or $6^{\circ} \mathrm{C}$ as function of time and examined the effects of temperature and time upon the AR. To account for low initial bacterial counts (a typical characteristic of high quality farm milk) and variations between milk from different farms more likely to be reflecting individual farm management practices, we studied commingled milk samples withdrawn from lorry tanks that constitute somehow an intermediate stage of the cold chain of raw milk storage and transportation.

\section{Materials and Methods}

2.1. Cold Storage of Raw Milk Samples. All raw bovine milk samples were obtained from lorry tanks of the Valio Ltd dairy company (Helsinki, Finland). Representative samples of the lorry contents were collected in sterile bottles, by licensed milk haulers shortly after the lorries arrived at the dairy. The samples were then kept on ice until arrival at Helsinki University, at which time $100 \mathrm{~mL}$ aliquots were added to sterile $250 \mathrm{~mL}$ bottles. Six bottles were placed on a multiplace magnetic stirrer (Variomag) and partially immersed in a refrigerated water bath (MGW Lauda MS/2), which allowed a constant temperature (monitored by an immersion thermostat) to be maintained (modified from [26]). The raw milk was continuously mixed at $220 \mathrm{rpm}$ and kept at $4 \pm 0.1^{\circ} \mathrm{C}$ or $6 \pm 0.1^{\circ} \mathrm{C}$ for 4 days.

\subsection{Enumeration of Bacterial Populations. Microbiological} analyses were performed immediately after milk samples arrived. All bacterial counts were determined from triplicate or quadruplicate agar cultures at days 0 (shortly after receiving the samples) and 4 for experiments $\mathrm{I}\left(4^{\circ} \mathrm{C}\right)$ and II $\left(6^{\circ} \mathrm{C}\right)$, and at days 2 and 4 for experiment III $\left(4^{\circ} \mathrm{C}\right)$, (Table 1$)$ by aseptically removing $500 \mu \mathrm{L}$ of raw milk, serially diluting the sample in a saline solution $(0.85 \% \mathrm{NaCl})$, and spreading $50 \mu \mathrm{L}$ on Mueller-Hinton (LabM) agar. Four antimicrobial agents (gentamicin $(\mathrm{G})$, ceftazidim (C), levofloxacin (L), and trimethoprim-sulfamethoxazole (TS at a ratio of 1/19) (Sigma)) were prepared according to the EUCAST guidelines [27]. The $A B$ solutions were freshly prepared by dissolving powders in the following solvents: water for $\mathrm{G}, 0.1 \mathrm{M}$ phosphate buffer ( $\mathrm{pH}$ 7) for $\mathrm{C}, 0.1 \mathrm{M} \mathrm{NaOH}$ for $\mathrm{L}, 0.1 \mathrm{M}$ lactic acid for T, and 95\% ethanol for S (EUCAST 2000). With the exception of $\mathrm{S}$, all $\mathrm{AB}$ solutions were filter sterilized, prior to the addition to adequately cooled agar. The $\mathrm{AB}$ concentrations were $16 \mathrm{mg} / \mathrm{L}$ for GI, $4 \mathrm{mg} / \mathrm{L}$ for GII, $32 \mathrm{mg} / \mathrm{L}$ for CI, $8 \mathrm{mg} / \mathrm{L}$ for CII, $8 \mathrm{mg} / \mathrm{L}$ for LI, $2 \mathrm{mg} / \mathrm{L}$ for LII, $8 \mathrm{mg} / \mathrm{L}$ trimethoprim with $152 \mathrm{mg} / \mathrm{L}$ sulfomethoxazole for TSI, and $4 \mathrm{mg} / \mathrm{L}$ trimethoprim with $76 \mathrm{mg} / \mathrm{L}$ sulfomethoxazole for TSII, which correspond to the MICs (GII, CII, LII, and TSII) to 4-fold the MIC (GI, CI, LI), or 2-fold the MIC (TSI) as indicated by EUCAST for pseudomonads. Agar plates were stored overnight at $4^{\circ} \mathrm{C}$ and protected from light. Following initial analysis, the plates were incubated for 2-3 days at $30^{\circ} \mathrm{C}$ or for 10 days at $7^{\circ} \mathrm{C}$ to enumerate the "total" bacteria (mainly mesophiles) and psychrotrophs, respectively.

\subsection{Statistical Methods. Two outputs were considered to} quantify AR. The first was AR prevalence, which is generally defined as the percentage of resistant bacteria considering the corresponding "total" bacteria enumerated in the same conditions, and the second was Rapd which was used to overcome perturbations due to excessive low versus high bacterial counts and variation among plates. Rapd is defined for a particular condition X and characterized by a combination of factors including population type (psychrotrophs (P) or mesophiles $(\mathrm{M}))$, sampling day $(\mathrm{d}=0,2$ or 4$)$, storage temperature, $\mathrm{AB}$ type, and $\mathrm{AB}$ concentration. Rapd corresponds to the number of bacterial colonies $(\mathrm{CFU} / \mathrm{mL})$ in a certain condition (determined by a combination of the previous listed factors) divided by the total number of bacteria on the corresponding control plates (in the absence of the $\mathrm{AB}$ ). To overcome variation between raw milk samples, which was mainly due to the initial microflora, statistical 


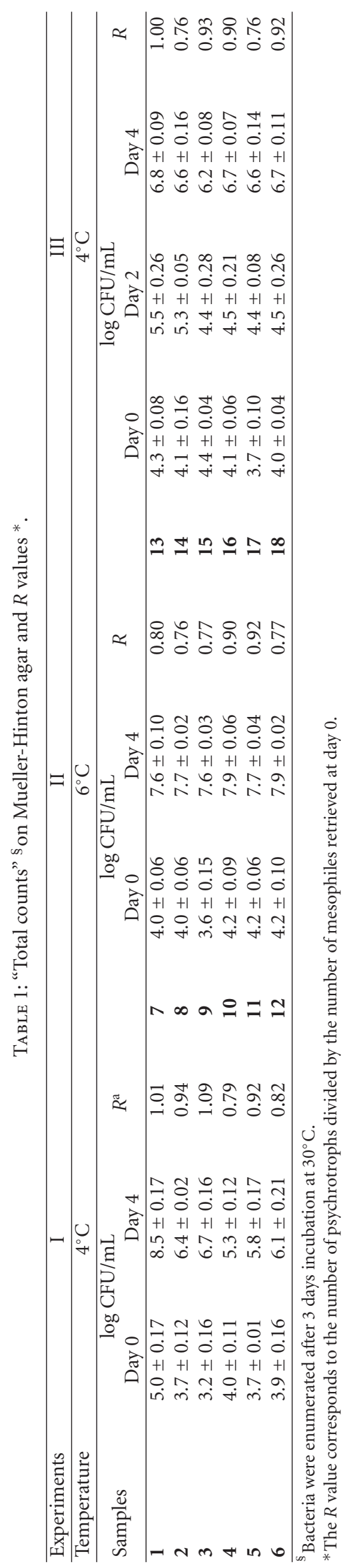


analyses were based on the rank of the Rapd instead of the Rapd itself. The use of the ranking enabled a more robust quantification of the AR regardless of the variation among the four considered factors (milk storage temperature and time, as well as $\mathrm{AB}$ type and concentration). The reliability of the results was determined by robust ANOVA and nonparametric statistics which are suited for analyses of heterogeneous data such as microbiological data.

The following statistical methods, previously applied [28], were also used for data analysis. (1) In a view of a simple description of data, usual statistical tools (USTs) for mean, standard deviation, median, and box-and-whiskersplots were generally used to represent bacterial enumeration (expressed as CFU/mL or in decimal log-units). (2) In a view to improve the robustness of the conclusions on ranked data, analysis of variance (ANOVA) on Rapd ranks as a function of the studied factors (milk storage temperature and time as well as $\mathrm{AB}$ type and concentration) was used to detect significantly influential factors (main effects or interaction effects). In the ANOVA framework, it is common to make multiple comparisons of means. Here, the RyanEinot-Gabriel-Welsch (REGW) test for multiple comparisons of ratio means was used. (3) Nonparametric statistics (NPSs), including Wilcoxon, Kruskal-Wallis, median twosample, and Van der Waerden tests, were used [29]. These analyses were performed using the NPAR1WAY procedure of the SAS/STAT statistical software (version 8.1) of the SAS Institute (NC, USA). The objective of these tests was to confirm or infirm statistically significant change of the Rap4 versus Rap0 means (Rapd, defined for one condition considering a combination of factors set at a particular level). For UST, the AR percentages were used to compare the number of mesophiles (or "total counts") with psychrotrophs, respectively. However, Rapd was used for ANOVA and NPS analyses.

\section{Results and Discussion}

3.1. Raw Milk Samples. The microbiological quality of the 18 analyzed raw milk samples was excellent: 17 of 18 samples had initial bacterial counts less than $5.0 \times 10^{4}$ $\mathrm{CFU} / \mathrm{mL}$ (4.7 in decimal log-units) (Table 1 ). At day 0 , the psychrotrophs/"total counts" ratios were lower than 0.9 in eight samples and higher than 0.9 in ten samples (Table 1). No correlation between the initial "total" bacterial load and the fraction of psychrotrophs present in raw milk samples was detected. Assuming that a higher ratio value corresponds to milk that spent more time in cold storage conditions, we estimate that the raw milk samples were subjected to "different storage times" prior to the analyses.

\subsection{AR Prevalence among Mesophilic versus Psychrotrophic Bacteria at the Start of the Analyses (Day 0) Evaluated for Each $A B$ and Bacterial Community Type}

3.2.1. Descriptive Statistics. The AR for each AB and population type is summarized in Figures 1 and 2. For the majority of the samples analyzed shortly after reception, higher AR percentages with larger box boundaries were observed with lower $A B$ concentrations regardless of the $A B$ type, which is indicative of an $\mathrm{AB}$-concentration-dependent response (Figures 1 and 2). With some exceptions, mesophilic populations $(M)$ had AR percentages with gentamycin $(G)$ of 0\%-3\% (GIM) and 1.1\%-9\% (GIIM) (Figure 1(a)). The psychrotrophic populations $(\mathrm{P})$ were more heterogeneous and exhibited slightly lower resistance to GIP (0\%-2\%) than GIIP (0\%-30\%). The AR prevalence to ceftazidim was higher than for the other tested ABs and was highest for the psychrotrophic populations on CII (Figure 1(b)); although the median values of CIP and CIM, and of CIIP and CIIM, showed only minor differences, the psychrotrophic populations had more heterogeneity in AR prevalence, especially for the lower ceftazidim concentration (CII). Approximately one-fourth of the samples had AR percentages of $50 \%-$ $100 \%$, and $38 \%-50 \%$ for CIIP and CIIM, respectively. AR to levofloxacin (L, Figure 1(c)) was the least prevalent among the considered antibiotics at both concentrations but was moderately higher for mesophiles than for psychrotrophs. The prevalence of AR to trimethoprim-sulfamethoxazole (TS, Figure 1(d)) was higher for the psychrotrophs (P) than mesophiles $(\mathrm{M})$ as indicated by the median values and boundaries of the box plots. The heterogeneity among samples was also highest for psychrotrophs.

The percentages of $A R$ observed with high $A B$ concentrations were less than those observed at low $\mathrm{AB}$ concentrations for all mesophilic populations and for 13 of 18 psychrotrophic populations. AB-concentration-dependent responses were apparent when considering the boundaries of the box-and-whiskers plots depicting the total AR percentages, comparing IM and IIM with IP and IIP (mesophiles (M) or psychrotrophs (P), present on plates with high (I) or low (II) antibiotic concentrations) (Figure 2). The median value observed for the psychrotrophs (IP) exceeded by $10 \%$ the value of the mesophiles (IM) with the highest $A B$ concentrations; the 75th percentiles had AR maximums of $70 \%$ (IP) and 52\% (IM); the top quartiles were comprised between $45 \%$ and $70 \%, 40 \%$, and $50 \%$ for the psychrotrophs (IP) and mesophiles (IM), respectively. The distribution of $\mathrm{AR}$ in the mesophiles was more homogeneous than in the psychrotrophs: half of the samples had total resistance percentages ranging from 50\% through 100\% (IM) and $30 \%$ through $130 \%$ (IP). Although the median value was slightly greater than $40 \%$ for both types of populations, with the low antibiotic concentrations half of the samples had total AR of $20 \%$ to $90 \%$ (IIP) and $30 \%$ to $60 \%$ (IIM) (Figure 2). The 75th interquartile had AR of $90 \%-135 \%$ (psychrotrophs) and 60\%-90\% (mesophiles), respectively. The total percentages of AR (evaluated using four ABs, regardless of concentration) never exceeded $100 \%$ for the mesophilic populations, contrarily to psychrotrophic populations present in four milk samples. This result could be indicative of a higher prevalence of multiresistant bacteria among psychrotrophs than mesophiles.

A link between "total initial counts", the psychrotrophs/ "total counts" ratios, and the number of encountered AR fractions among psychrotrophs versus mesophiles in a given raw milk sample is not apparent. For example, sample 8 had 


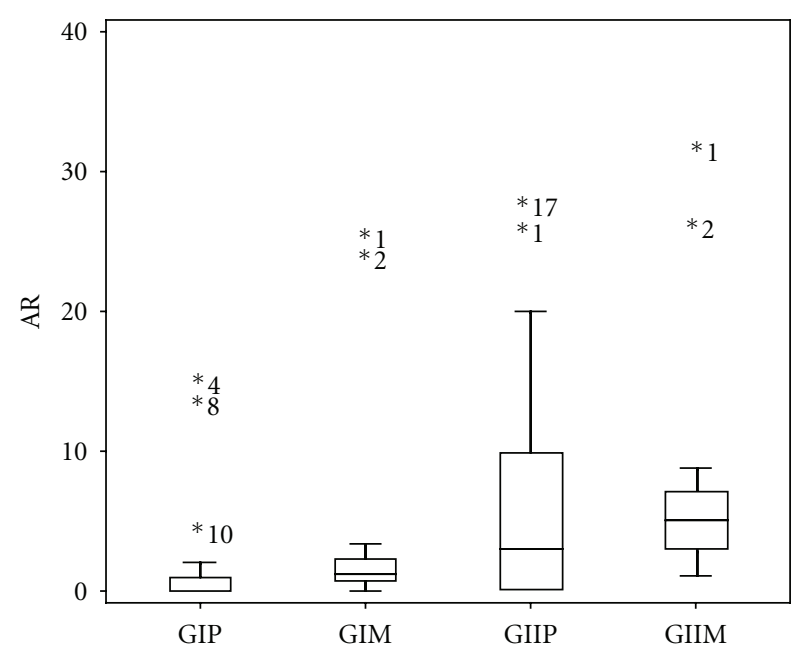

(a)

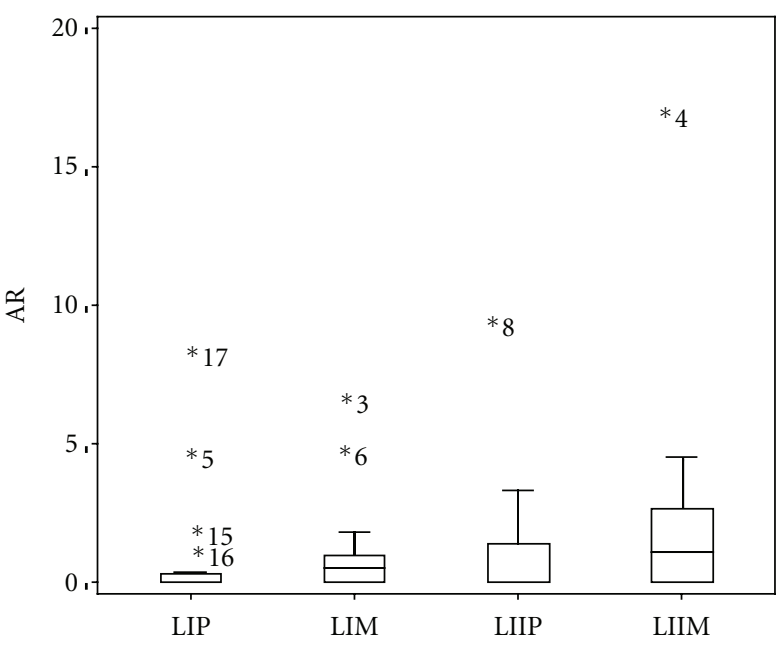

(c)

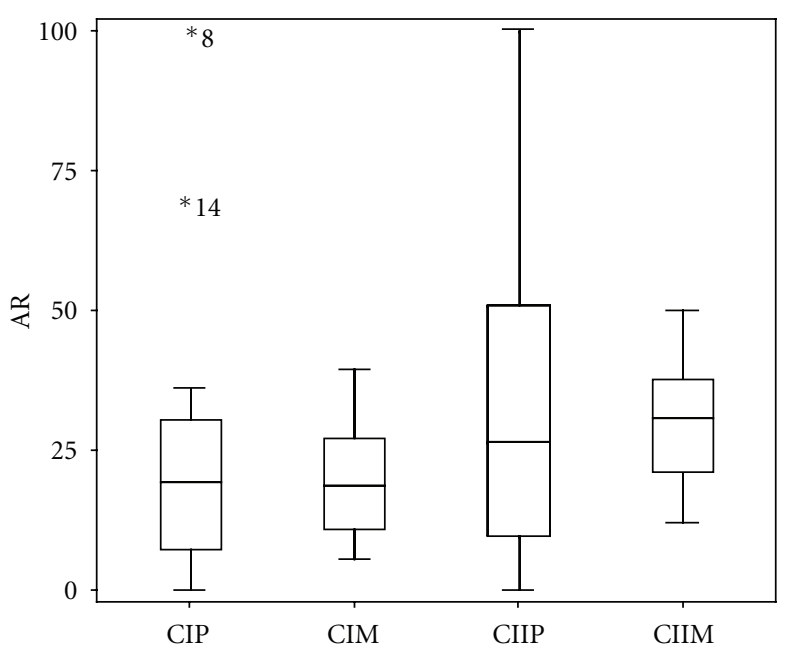

(b)

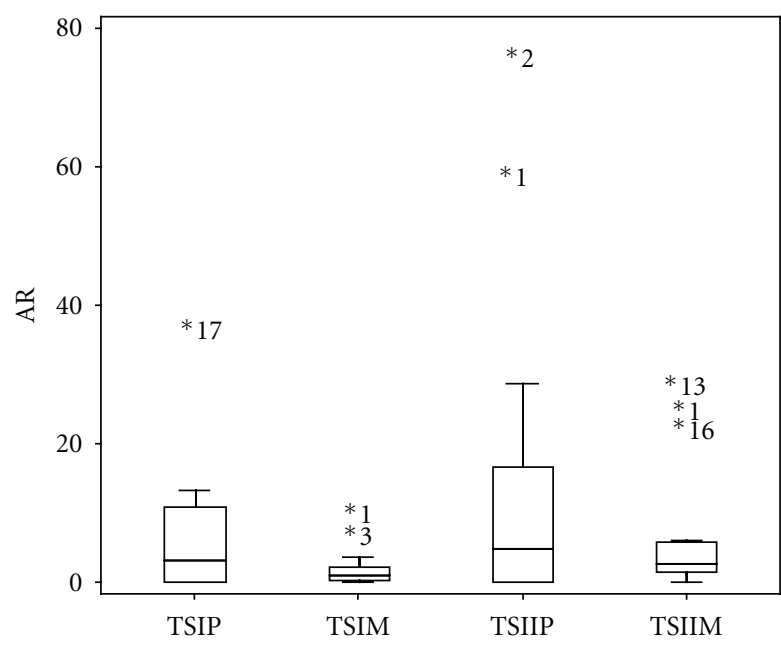

(d)

FIgure 1: Box- and-whiskers plots of the initial AR percentages distributions. The AR values correspond to gentamicin (G, 1a), ceftazidim $(\mathrm{C}, 1 \mathrm{~b})$, levofloxacin $(\mathrm{L}, 1 \mathrm{c})$, and trimethoprim-sulfamethoxazole (TS, 1d) for psychrotrophic (P) and mesophilic (M) bacterial populations $(\mathrm{I}=4 \times$ MIC for G, C, L and $2 \times$ MIC for TS; II = MIC). The inner box lines represent the geometric medians, while the outer box lines represent the 25th and 75th data percentiles; the outliers are indicated beside their sample number. Sample 8 that showed an AR of $100 \%$ for GIIP is not included in Figure 1(a).

low initial counts and a low psychrotrophs/mesophiles ratio but revealed the highest AR for the psychrotrophs, which greatly exceeded the AR of the corresponding mesophiles.

The AR was less dependent on the "age of the raw milk" (the time that elapsed between milking and the time of analyses which could be somehow estimated from ratios of psychrotrophs/mesophiles) but rather more dependent on the initial bacterial microflora.

3.2.2. ANOVA Results. The mean values of the Rap0 ratios determined at day 0 were 0.2396 and 0.3448 (C), 0.0544 and 0.0676 (G), 0.0485 and 0.0939 (TS), and 0.0171 and 0.0086 (L) for the mesophiles and psychrotrophs, respectively. Regardless of the bacterial population type, AR was most prevalent for $\mathrm{C}$ and least for $\mathrm{L}$. With the exception of $\mathrm{L}$, all mean Rap0 values analyzed with the REGW test for psychrotrophs were superior to those observed for mesophiles which confirmed previous observations (Section 2.1). ANOVA performed on Rap0 and on Rap0 rank (see Rap0 definition in section 2) revealed significant main effects for the mesophiles. $F$ values (from the Fisher-Snedecor test, $P<0.0001)$ were 82.73, 176.95, and 40.27 for storage temperature, $\mathrm{AB}$ type, and $\mathrm{AB}$ concentration, respectively. The effects due to $A B$ type and the interaction between storage temperature and $A B$ type were partially sample dependent. The REGW range test for Rap0 considered the four ABs distinct, but the effects of L and TS were similar. To overcome perturbations due to sample 1, which was considered different (highest Rap0 mean value), a second REGW range test was performed for Rap0 after eliminating the sample 1; the test confirmed the importance of the considered factors. The $F$ values (from the 


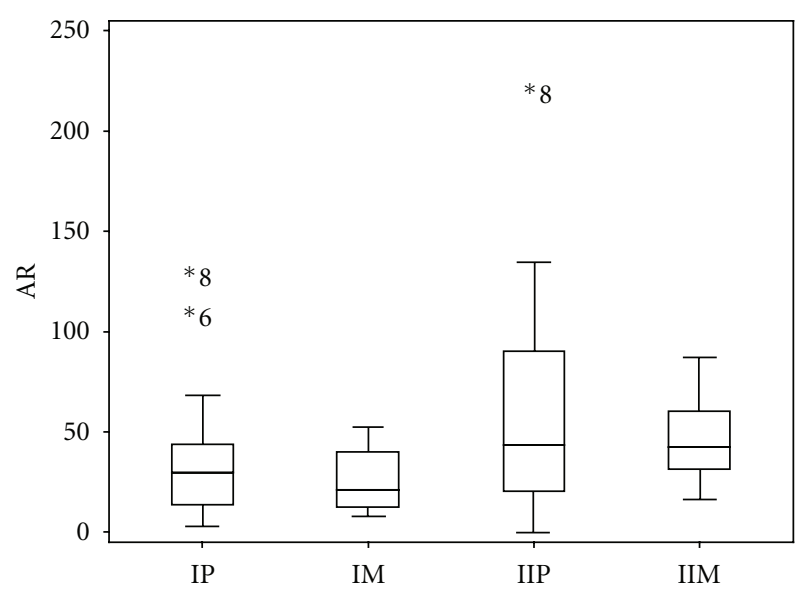

Figure 2: Box- and-whiskers plots of the distribution of the total initial AR percentages for psychrotrophs $(\mathrm{P})$ and mesophiles (M). The AR values correspond to the two $\mathrm{AB}$ concentrations ( $\mathrm{I}=4 \times$ MIC for G, C, L, and $2 \times$ MIC for TS; II = MIC). Outliers are indicated under their sample number.

Fisher-Snedecor test, $P<0.0001)$ were 20.22, 108.96, and 20.14 for storage temperature, $\mathrm{AB}$ type, and concentration, respectively, for samples 2-6. Both approaches confirmed the ranking of the $\mathrm{ABs}$ according to their decreasing prevalence: C, G, TS, and L.

The AR for psychrotrophs was more sample dependent ( $F$ value of $18.35, P<0.0001)$. A significant difference was observed for the four ABs ( $F$ value of 68.84, $P<0.0001$ ), and significant interactions between storage temperature and sample ( $F$ value of 15.31) were detected. Unlike the mesophiles, the encountered variability relied on a high sample/temperature interaction. The REGW multiple range test ranked $\mathrm{C}$ and $\mathrm{L}$ in the 1 st and 4 th positions, respectively, in AR prevalence for both mesophiles and psychrotrophs. G and TS were ranked in 2nd and 3rd position, respectively, for the mesophiles; the rankings were reversed for the psychrotrophs where the AR to TS was the second most prevalent. The analyses considered the four $\mathrm{ABs}$ distinct, although TS and L induced similar AR levels for the mesophiles, whereas TS and G induced similar AR levels for the psychrotrophs.

\subsubsection{Evolution of the AR of Psychrotrophic Populations from} Two Raw Milk Samples (13 and 16, Table 1) Stored at $4^{\circ} \mathrm{C}$ for 4 Days. Figure 3(a) depicts the trend of ceftazidimresistant psychrotrophs (CI) which nearly parallels the total psychrotrophic population in raw milk sample (13); the differences were approximately $0.7,1$, and up to 2 log-units at days 0,2 , and 4 , respectively. While no resistant isolates were detected on day 0 on trimethoprim-sulfamethoxazole (TSI) plates, the AR reached the level of C-resistant isolates (about $3.5 \log$-units) at day 2. The growth kinetics between days 2 and 4 were almost undistinguishable between isolates recovered from CI and TSI plates. A similar trend (when compared to TSI) was observed for gentamicin (GI), where the counts were approximately 2 and $3 \log$-units at days 2 and 4, respectively, which followed the trend of the control but were 2.5 and 3 log-units lower than the counts on control plates. Although not detected at day 0, levofloxacin-resistant (LI) isolates were present on day 2 at a level of 3 log-units but declined to approximately $2 \log$-units at day 4 . No differences were observed between isolates grown on CII and TSII plates, compared to the trends observed for CI and TSI, respectively (Figure 3(b)). The AR levels detected on GII and LII were in the same range (approximately 2-3 log-units) but inverted compared to GI and LI; these differences may be due to low bacterial counts on L plates.

Sample 16 showed similar trend to sample 13, at day 2 for $\mathrm{C}$ and TS at the high $\mathrm{AB}$ concentrations (Figure 3(c)), but the initial counts with CI were 2 log-units higher than those from TSI plates. The initial psychrotrophic population had a high level of C-resistance (CI); a second "wave" of psychrotrophs, TS-resistant, was established after $48 \mathrm{~h}$. As with sample 13, the counts on TS plates at day 4 were higher than those from C, suggesting that TS- and C-resistant psychrotrophs may not be the same isolates over time. If after 2 days of storage at $4^{\circ} \mathrm{C}$ bacterial isolates were resistant at levels of approximately $3,3.5$, and $4 \log$-units (of a total of 4.5 ) to $\mathrm{G}$, $\mathrm{C}$, or TS, respectively (for the lower $\mathrm{AB}$ concentration II, e.g., Figure 3(d)), we would assume that most had multiresistant features.

Together, the lower prevalence of TS-resistance compared to C-resistance at day 0 and the higher prevalence of TSresistance than $\mathrm{C}$-resistance at day 4 suggest that a first wave of psychrotrophs which is more C-resistant is replaced by a second population that is more TS-resistant. The second wave also frequently had G-resistant features; the resistance was after 2-day storage for 5 of 6 samples, about 2-3.5 log units lower compared to the corresponding controls. For most of these samples, no isolates grew on G-containing plates at day 0 or were present at low numbers ( 1 out of 100). Figures 3(a)-3(d) suggest a succession of psychrotrophic communities distinguishable by the prevalence of $\mathrm{AR}$ to the four $\mathrm{ABs}$ (representatives of four different $\mathrm{AB}$ classes) considered in this study, although a detailed analysis of the kinetics of the psychrotrophs that expressed AR features revealed a sample-dependent dynamic.

\subsubsection{Evaluation of $A R$ for Raw Milk Samples Stored at $4^{\circ} \mathrm{C}$ and $6^{\circ} \mathrm{C}$ for 4 Days}

Descriptive Statistics. The effect of cold storage on the AR of psychrotrophs (P) and mesophiles (M) was investigated at $4^{\circ} \mathrm{C}$ and $6^{\circ} \mathrm{C}$ for samples $1-6$ and 7-12, respectively (Table 1). The "total counts" and psychrotrophs, enumerated on Mueller-Hinton plates without antibiotics, from samples stored at $6^{\circ} \mathrm{C}$ for $4 \mathrm{~d}$, exceeded initial counts by 3.5-4 log-unit, and 4-5 log-units for the mesophiles and psychrotrophs, respectively (Table 1). Increases of 2-3.5 logunit, and 2-3 log-unit for the mesophiles and psychrotrophs, respectively, were recorded when milk samples were stored at $4^{\circ} \mathrm{C}$ for 4 days, with the exception of sample 4 in which both populations types increased by approximately 1.5 log-units (Table 1). Samples 7-12 (Table 1) which were stored at $6^{\circ} \mathrm{C}$ 


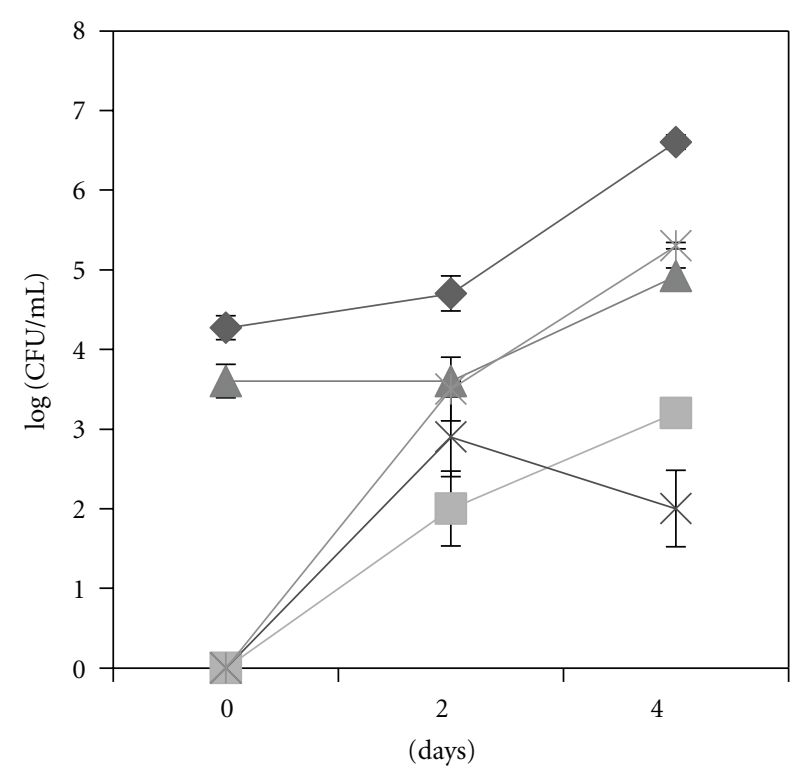

(a)

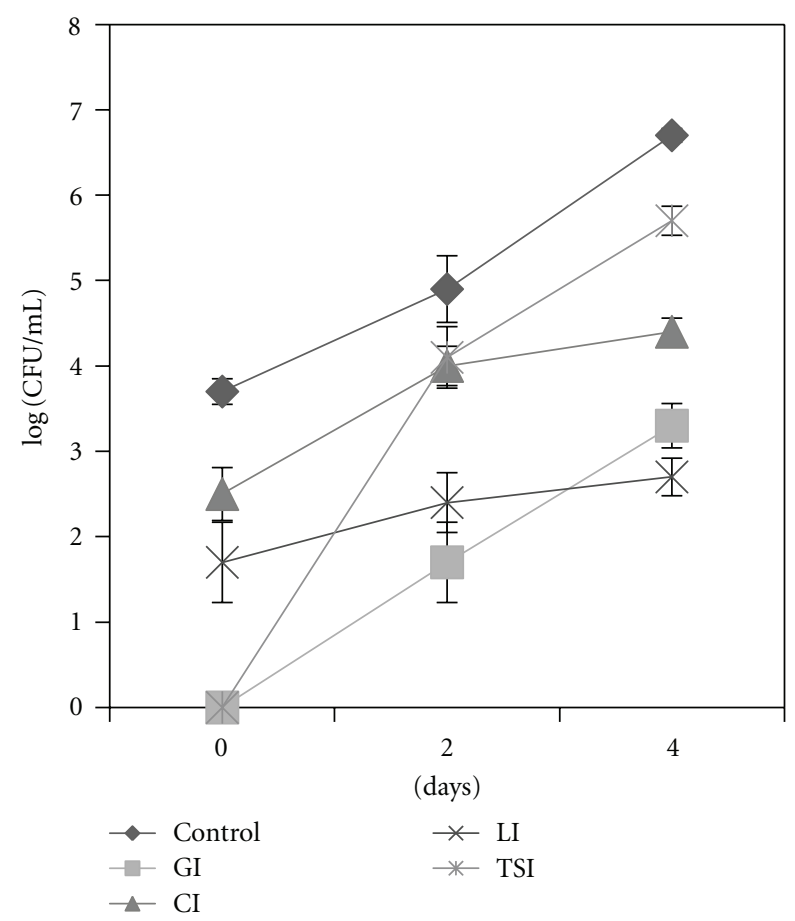

(c)

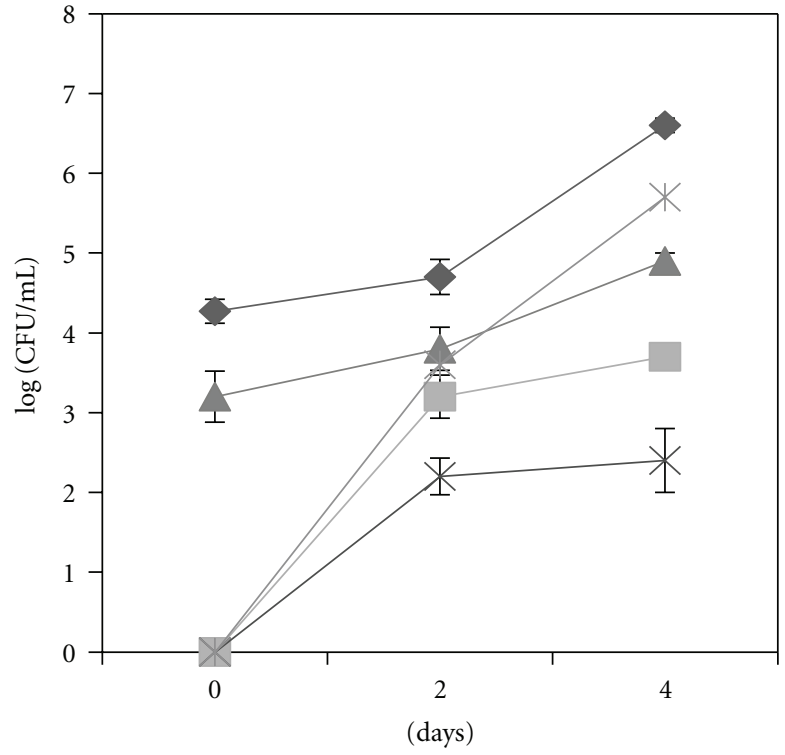

(b)

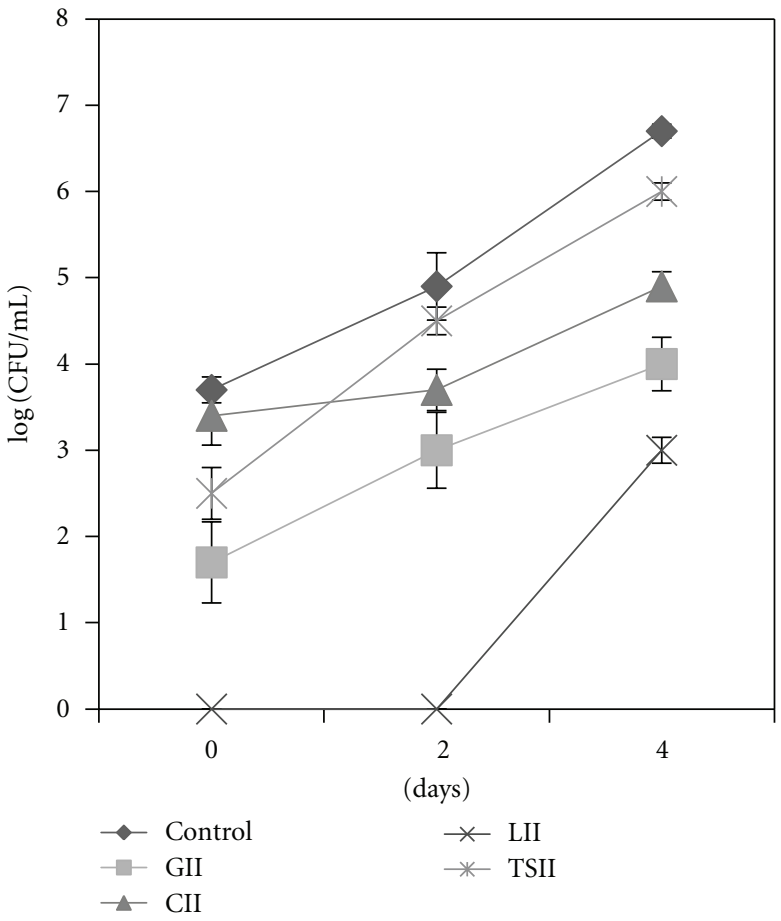

(d)

FIGURE 3: AR trend of psychrotrophs in raw milk samples 13 (a and b) and 16 (c and d).

exhibited the highest resistance at day 0 to ceftazidim (C): the AR levels ranged between 0 (sample 12) and 100\% (sample 8) for both CIP and CIIP. With the exception of sample 8, in which psychrotrophs exhibited the highest $A R$ to $C, L$, and TS, the AR for the mesophiles and psychrotrophs was low. After 4 days of storage, the AR generally decreased for all samples.

Samples 1-6 (Table 1), which were stored at $4^{\circ} \mathrm{C}$, had the highest initial resistance levels to CII (31.4\%-50\% CIIM;
7.3\%-56.7\% CIIP) and to CI (20.5\%-38.2\% CIM; $7.3 \%-$ $100 \%$ CIP) but also had higher AR to the other ABs in samples 1 and 2 (e.g., $27.2 \%$ for GIIP and $56.1 \%$ for TSIIP in sample 1) and to a lesser extent for samples 4 and 5.

ANOVA Results. The statistical analyses that distinguished the following factors (storage temperature of the milk, $\mathrm{AB}$ type, $\mathrm{AB}$ concentration, and bacterial population type) are detailed in Table 2. The determination of Rapd values 
TABLE 2: Trend of Rap4 compared to Rap0 determined for raw milk samples 1-12.

\begin{tabular}{|c|c|c|c|c|}
\hline Milk storage temperature & $\mathrm{AB}$ & $\mathrm{AB}$ concentration & Population type & Rap4 compared to Rap0 $0^{\S}$ \\
\hline \multirow{4}{*}{$4^{\circ} \mathrm{C}$} & \multirow{8}{*}{ G } & \multirow{2}{*}{ I } & $\mathrm{M}$ & Rap $4<$ Rap0 \\
\hline & & & $\mathrm{P}$ & Rap4 > Rap0 \\
\hline & & \multirow{2}{*}{ II } & M & Rap4 < Rap0 \\
\hline & & & $\mathrm{P}$ & Rap4 = Rap0 \\
\hline \multirow{4}{*}{$6^{\circ} \mathrm{C}$} & & \multirow{2}{*}{ I } & M & Rap4 = Rap0 \\
\hline & & & $\mathrm{P}$ & Rap4 > Rap0 \\
\hline & & \multirow{2}{*}{ II } & M & Rap4 $<$ Rap0 \\
\hline & & & $\mathrm{P}$ & Rap4 = Rap0 \\
\hline \multirow{4}{*}{$4^{\circ} \mathrm{C}$} & \multirow{8}{*}{$\mathrm{C}$} & \multirow{2}{*}{ I } & M & Rap4 < Rap0 \\
\hline & & & $\mathrm{P}$ & Rap4 < Rap0 \\
\hline & & \multirow{2}{*}{ II } & M & Rap4 < Rap0 \\
\hline & & & $\mathrm{P}$ & Rap4 < Rap0 \\
\hline \multirow{4}{*}{$6^{\circ} \mathrm{C}$} & & \multirow{2}{*}{ I } & M & Rap4 < Rap0 \\
\hline & & & $\mathrm{P}$ & Rap4 = Rap0 \\
\hline & & \multirow{2}{*}{ II } & M & Rap4 < Rap0 \\
\hline & & & $\mathrm{P}$ & Rap4 = Rap0 \\
\hline \multirow{4}{*}{$4^{\circ} \mathrm{C}$} & \multirow{8}{*}{$\mathrm{L}$} & \multirow{2}{*}{ I } & M & Rap4 = Rap0 \\
\hline & & & $\mathrm{P}$ & Rap4 = Rap0 \\
\hline & & \multirow{2}{*}{ II } & M & Rap4 = Rap0 \\
\hline & & & $\mathrm{P}$ & Rap4 = Rap0 \\
\hline \multirow{4}{*}{$6^{\circ} \mathrm{C}$} & & \multirow{2}{*}{ I } & M & Rap4 > Rap0 \\
\hline & & & $\mathrm{P}$ & Rap4 > Rap0 \\
\hline & & \multirow{2}{*}{ II } & M & Rap4 > Rap0 \\
\hline & & & $\mathrm{P}$ & Rap4 > Rap0 \\
\hline \multirow{4}{*}{$4^{\circ} \mathrm{C}$} & \multirow{8}{*}{ TS } & \multirow{2}{*}{ I } & M & Rap4 = Rap0 \\
\hline & & & $\mathrm{P}$ & Rap4 = Rap0 \\
\hline & & \multirow{2}{*}{ II } & M & Rap4 > Rap0 \\
\hline & & & $\mathrm{P}$ & Rap4 = Rap0 \\
\hline \multirow{4}{*}{$6^{\circ} \mathrm{C}$} & & \multirow{2}{*}{ I } & M & Rap4 = Rap0 \\
\hline & & & $\mathrm{P}$ & Rap4 > Rap0 \\
\hline & & \multirow{2}{*}{ II } & M & Rap4 = Rap0 \\
\hline & & & $\mathrm{P}$ & Rap4 > Rap0 \\
\hline
\end{tabular}

${ }_{\S}$ The results correspond to the comparisons of the means of the Rapd values, from sampling days 0 and 4 , by the NPS tests which are significant at the 0.01 level (for all tests performed).

as superior, inferior, or equal was based on the results of the mean comparisons of the Rapd values that were significantly superior, inferior or equal by the NPS tests. For the mesophiles $(\mathrm{M})$, cold storage $\left(4^{\circ} \mathrm{C}\right.$ or $\left.6^{\circ} \mathrm{C}\right)$ decreased the prevalence of AR to ceftazidim (C), regardless of storage temperatures, or $\mathrm{AB}$ concentration. Rap4 was lower than Rap0 for GI or GII at $4^{\circ} \mathrm{C}$ or $6^{\circ} \mathrm{C}$, with the exception of GIM in which Rap4 was equal to Rap0. For trimethoprimsulfamethoxazole (TS), Rap4 values were equal to Rap0, with the exception of TSIIM, where Rap4 was superior to Rap0. Although levofloxacin-resistant isolates were the most rare, Rap4 was equal to or greater than Rap0 when milk samples were stored at $4^{\circ} \mathrm{C}$ or $6^{\circ} \mathrm{C}$, respectively.

The trends for gentamicin-resistant psychrotrophs (P) were similar at $4^{\circ} \mathrm{C}$ and $6^{\circ} \mathrm{C}$ (Table 2). Rap4 exceeded or was equal to Rap0 for GI and GII, respectively. Ceftazidimresistance diminished after 4 days of storage at $4^{\circ} \mathrm{C}$ at both concentrations (CI, CII), but Rap4 values remained at the initial level in milk samples stored at $6^{\circ} \mathrm{C}$. The observations with levofloxacin (L) and trimethoprim-sulfamethoxazole (TS) (Table 2) suggest that the milk storage temperature $\left(4^{\circ} \mathrm{C}\right.$ or $6^{\circ} \mathrm{C}$ ) affected the AR trend, because at $6^{\circ} \mathrm{C}$, all Rap4 exceeded the Rap0 values.

Bacterial growth is temperature dependent; even at low temperatures, a rise of $2^{\circ} \mathrm{C}$ enables the growth of more bacterial psychrotrophic species or genera [4] which was also verified in this study as "total counts" at $6^{\circ} \mathrm{C}$ were usually higher than those at $4^{\circ} \mathrm{C}$ (Table 1$)$. Although, the study could not consider identical samples in both storage temperature conditions simultaneously, the AR trends obtained with four 
different $A B s$ types (Table 2) suggest that the lowest storage temperature was most appropriate to contain $\mathrm{AR}$ at the minimal level.

\subsubsection{AR Evaluated at Days 0, 2, and 4 during Storage of Raw Milk at $4^{\circ} \mathrm{C}$}

Descriptive Statistics. The counts from samples 13-18 at day 2 (Table 1) revealed a moderate increase compared with the initial bacterial load; at day 4, all counts exceeded 6 log-units on Mueller Hinton plates. At day 0, the AR prevalence was highest for ceftazidim whether considering the mesophiles $(6.7 \%-39.5 \%$ and $13.8 \%-40 \%$ for CIM and CIIM, resp.) or psychrotrophs $(4.4 \%-68 \%$ and $9.6 \%-50.9 \%$ for CIP and CIIP, resp.) (Figure 4(a)). Samples 14 and 17 had an AR prevalence of $16 \%$ and $28.6 \%$, respectively, to gentamicin considering the psychrotrophs (GIIP). The highest AR prevalence for trimethoprim-sulfamethoxazole (TS) was observed for psychrotrophs in sample 17 and for mesophiles in sample 13. The lowest AR prevalence recorded was for levofloxacin (L) in both populations types (Figure 4(a)).

Altogether the highest percentages of resistance were observed at day 2, and a sample-dependent shift was noticeable between days 0 and 2 (Figure 4(b)). An increase of AR was observed for sample 15 between days 0 and 2 for both mesophiles and psychrotrophs, whereas the trend was opposite in sample 17. Mesophiles from sample 16 and psychrotrophs from sample 18 exhibited up to $100 \%$ TSresistance (Figure 4(b)). In terms of "total counts", day 2 was an important sampling time point because the threshold level of $10^{5} \mathrm{CFU} / \mathrm{mL}$ was crossed in many samples.

At day 4, resistance to TS was the most prevalent, followed by resistance to C. The G- and L-resistant isolates were more rare but present at similar levels for both mesophiles and psychrotrophs (Figure 4(c)). When every AB is examined individually, the observation was made in a previous study that TS-resistance was more prevalent among isolates that spent a longer time in cold storage conditions, which was also noticed to some extent for some $\beta$-lactams antibiotics [25].

ANOVA Results. The statistical analyses revealed the same ranking of the four $\mathrm{ABs}$ for the mesophiles or the psychrotrophs regardless of the sampling day. C-resistance was the most prevalent at day 0 , followed by TS, G, and L. At days 2 and 4, TS supplanted $C$ without affecting the order of the two other ABs. The AR estimated through Rap0, Rap2, and Rap4 values for both types of populations was always the highest for psychrotrophs (Table 3 ). The range of variation of the Rap values, which were higher for psychrotrophs, confirmed higher heterogeneity among psychrotrophic communities. Most importantly, all Rap values were at their maximum for mesophiles and psychrotrophic populations at day 2, which corresponded to 48 hours storage at $4^{\circ} \mathrm{C}$ (Table 3).

Finnish raw milk is considered as excellent, with regard to both microbial loads and $\mathrm{AB}$ residues $[30,31]$. The
AR levels reported here and the trend of AR during cold storage raise the questions regarding the origin of $\mathrm{AR}$ and multiple AR in raw milk psychrotrophs. A direct link between the frequency of $\mathrm{AB}$ use and $\mathrm{AR}$, which has been described worldwide, may be part of the explanation. In Finland, the prudent use of antimicrobials recommends that streptococci and $\beta$-lactamase-negative-staphylococci causing mastitis should be treated with systemically administered benzyl penicillin ( $\beta$-lactams) [32] or intramammarily administered $\beta$-lactams combined with aminoglycosides [33]. The use of $3 \mathrm{rd}$ and 4 th generation cephalosporins (like ceftazidim) in cattle is not permitted [32]. Acute clinical mastitis caused by Gram-negative bacteria may be treated systemically with trimethoprim-sulphonamide or enrofloxacin (fluoroquinolone) and severe coliform mastitis cases (approximately 12\% of the cases in Finland) are treated with fluoroquinolones [32, 33].

Considering the $\mathrm{AB}$ classes considered here (ceftazidim$\beta$-lactams, gentamicin-aminoglycosides, levofloxacin-quinolones, trimethoprim-sulfamethoxazole-folate pathway inhibitors), the differences in AR prevalences somehow reflect the $A B$ usage frequencies with the exception of ceftazidim which is a third-generation cephalosporin for which coselection by other antimicrobials seems to influence resistance prevalence [34]. Although many agents can cause bovine mastitis (mammary gland infection), pathogens that induce clinical symptoms are mainly Gram-positive bacteria [35], whereas psychrotrophs are widely distributed among Gramnegative and less so among Gram-positive species [6]. Several studies that investigated the spoilage potential of raw milk psychrotrophs indicated that at the time of the spoilage, Gram-negative bacteria dominate the microflora [2]; however, the Gram status does not limit the transfer of AR traits $[36,37]$. Since, apart from the cold storage, no other stress was applied to raw milk samples, the dominant factor that conducts the successional dynamics of the bacterial communities was resource availability over time. Considering the AR prevalence (Figures 3 and 4), three categories of bacteria could be roughly distinguished, as follows. (1) The first stage starts from the milking step and lasts until the dominance of psychrotrophs, in which the bacterial diversity (considering the numerous contamination sources) could be rather high. These bacteria are not yet so well adapted to cold storage, and nutrients are limited. The AR may be variable but not negligible. This stage could correspond to the domination of oligotrophs [38], depicted in Figure 3 (day 0) and Figure 4(a). (2) In the second stage, a pioneering group of psychrotrophs that produce exoenzymes (proteases, lipases, phospholipases) that degrade milk components (fats, proteins, carbohydrates, etc.) are dominant. This stage could constitute a transitory step between oligotrophs and copiotrophs $[38,39]$ and could correspond to communities plotted in Figure 4(b), for which the AR was highest. (3) In the third stage, four days of cold storage selected for authentic psychrotrophs that grow in a "richer" media and could be psychrotrophic copiotrophs (Figure $4(\mathrm{c})$ ). AR is at its minimum in terms of relative amounts, which could suggest that carrying AR features may not be advantageous anymore. This hypothesis would be 


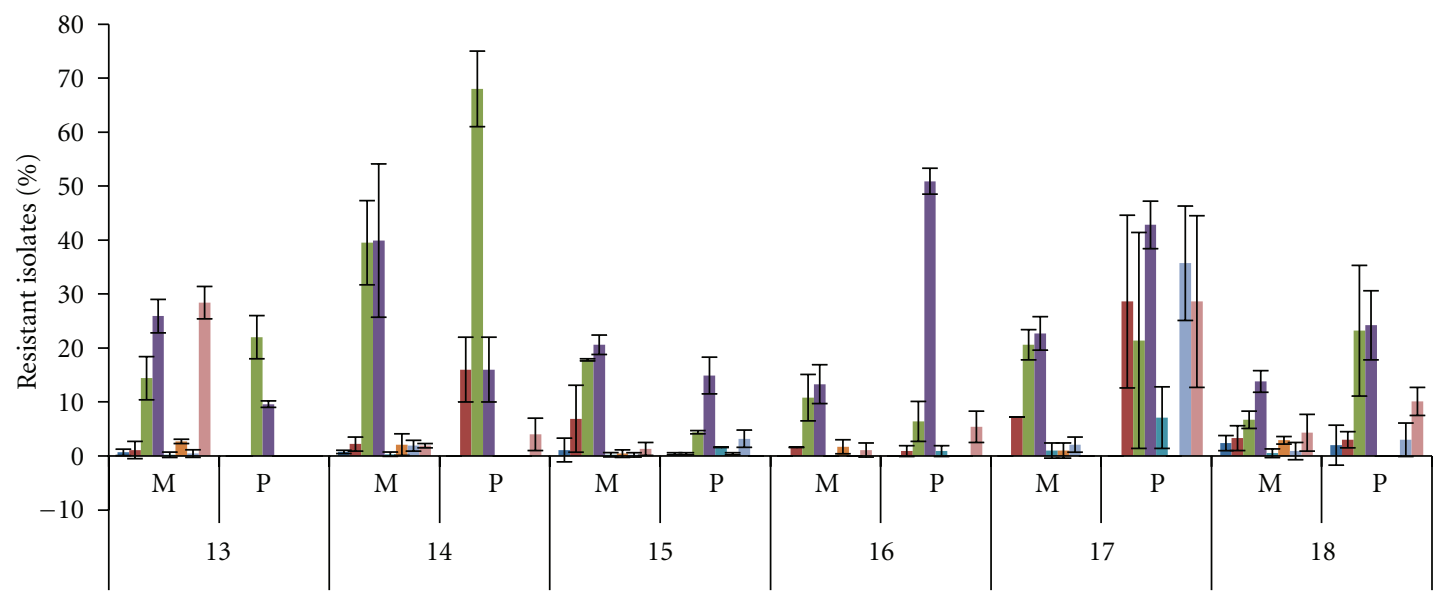

Samples

(a)

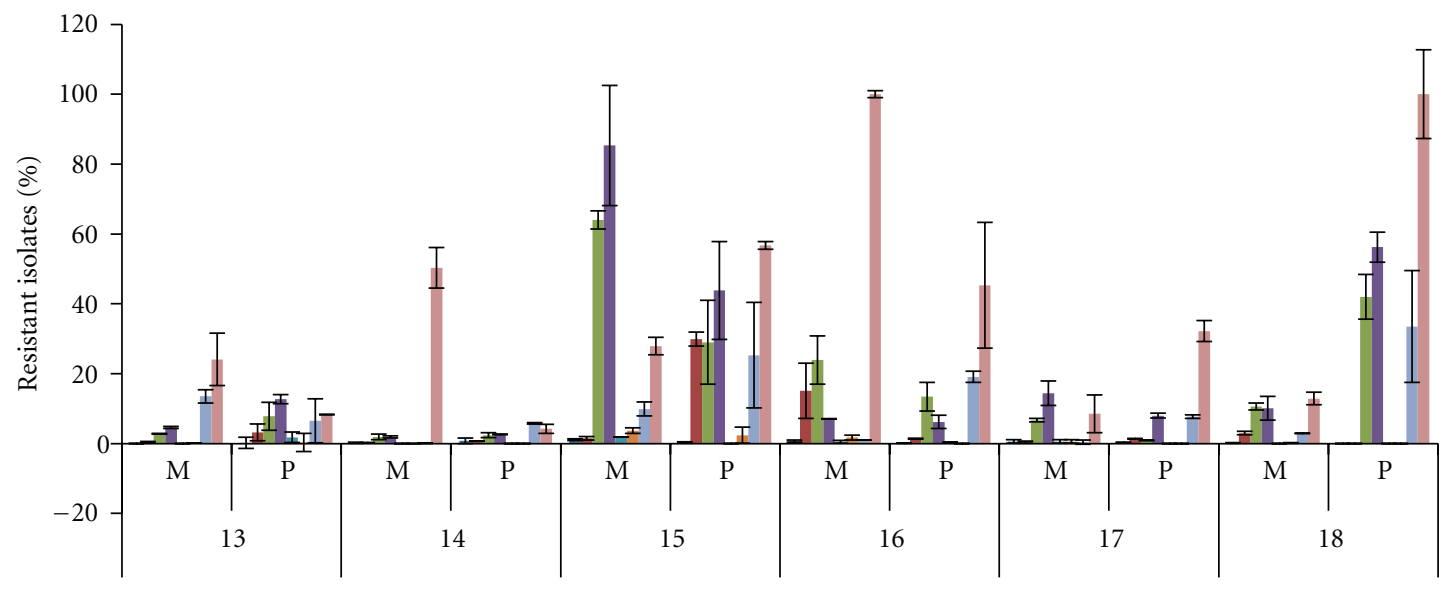

Samples

(b)

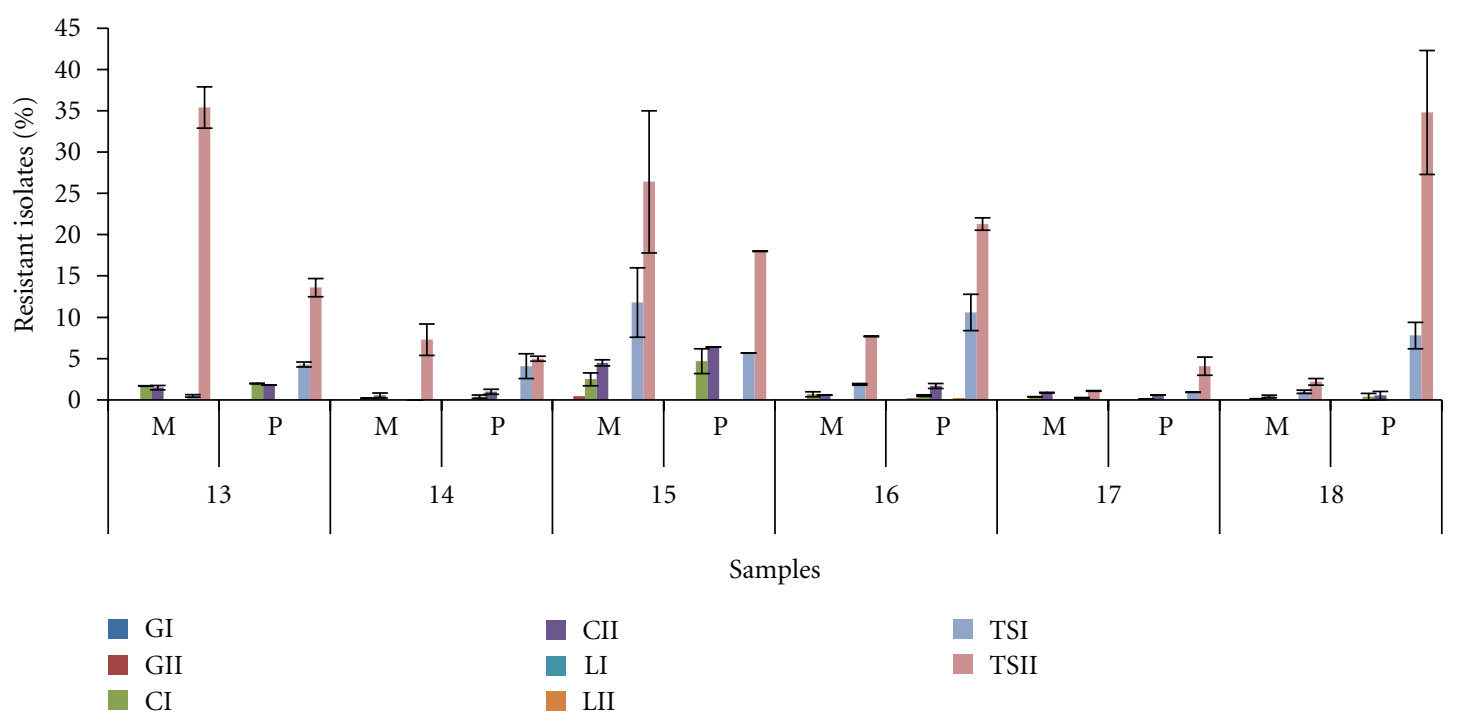

(c)

Figure 4: Percentages of resistant mesophiles (M) and psychrotrophs (P). Raw milk samples 13-18 were stored for 4 days at $4{ }^{\circ} \mathrm{C}$ : day 0 (a), day 2 (b), and day 4 (c). 
TABLE 3: Mean values of Rapd $(\mathrm{d}=0,2,4)$ and their corresponding range ${ }^{\S}$.

\begin{tabular}{lcccccc}
\hline & \multicolumn{3}{c}{ Mesophiles } & \multicolumn{3}{c}{ Psychrotrophs } \\
\hline Rapd & Rap0 & Rap2 & Rap4 & Rap0 & Rap2 & 0.0439 \\
\hline Mean & 0.0788 & 0.2186 & 0.02402 & 0.1387 & 0.3336 & $0-9.0333$ \\
Range & $0-1.1368$ & $0-5.2363$ & $0-0.5741$ & $0-3.0000$ & $0-000$ & 0 \\
\hline
\end{tabular}

${ }^{\S}$ determined for samples 13-18.

in line with the thought that bacteria produce $A B s$ to kill or inhibit neighbouring bacteria when nutrients are limited $[40,41]$. Considering that antimicrobial resistance mechanisms are associated with a fitness cost (which noticeably affects the bacterial growth rate) [42], we assume that the psychrotrophic enzyme producers that dominated at day 2 (Figure 4(b)) are outcompeted by a following psychrotrophic wave established at the cost of the enzyme producers. This wave multiplies quickly and carries fewer AR features (Figure 4(c)).

Considering the AR load, milk at day 4 could have a lower risk (lower AR percentages) though this milk is spoiled and inappropriate for consumption. Noteworthy Figures $4(\mathrm{a})-4$ (c) indicate a considerable drop of the relative AR rates while the number of isolates that carry $\mathrm{AR}$ features continuously increased (Figures 3(a)-3(d)).

Many genera constitute the rather highly diverse psychrotrophic raw milk microflora that enters the milk via numerous sources of contaminations $[2,5]$; if many are considered benign and only regarded as spoiling agents, the presence of others, such as Stenotrophomonas or Acinetobacter, should be seriously considered due to their innate resistance to many $\mathrm{ABs}$. Bacteria resistant to multiple $\mathrm{ABs}$, known as superbugs, constitute one of the most challenging problems faced by modern medicine. One class is comprised of opportunistic pathogens, often of environmental origin that infect sick and immunocompromised patients [10, 14]. Still, little is known about the antibiotic resistomes of the majority of environmental bacteria [43].

This study revealed that no direct correlation can be made between $\mathrm{CFU} / \mathrm{mL}$ values and AR prevalence. This addresses the question of whether the $10^{5} \mathrm{CFU} / \mathrm{mL}$ threshold "standard" is sufficient to ensure the quality and safety of raw milk. Indeed, heat treatments (pasteurization, UHT, etc.), to which raw milk is subjected, kill most or all bacteria; however, the results presented in this communication raise the question about the fate of all ARs genes loaded in mesophiles and psychrotrophs that may be released following heat treatment of raw milk.

Some psychrotrophs isolated from 4 days-stored milk were subjected to rapid phenotypic characterization. According to the API 20NE database, some of the multiresistant isolates belonged to the species Sphingomonas paucimobilis, Sphingobacterium spiritivorum, Chryseobacterium meningosepticum, and Stenotrophomonas maltophilia (data not shown). Additional studies are necessary to accurately identify the bacterial species or genera that constitute the different communities and determine the link if any between AR load and ecological attributes (appartenance to copiotrophic or oligotrophic communities). The diversity of the different bacterial populations and their dynamics should be investigated by both culture-dependent and molecular methods.

AR trends determined from the farm until the dairy silo would enable further evaluation of the present observations, further explanation on the impact of the cold chain on $\mathrm{AR}$, and discussion of eventual connection between animal and human health. Strategies to limit the bacterial load of mesophiles and psychrotrophs in raw milk should be designed to dispel technological risks and simultaneously consider human health aspects. The cold chain of raw milk storage and transportation may be still seen as an amplification of benign bacteria, in their majority; however, the interplay between many benign and some risky bacteria should not be overlooked in a world that struggles with superbugs.

\section{Conclusion}

The storage temperature and the antibiotic type influenced the AR prevalence, despite sample variations. During cold storage, different psychrotrophic communities that carry different AR levels seem to succeed to each other over time. When evaluated from relative amounts whether for psychrotrophs or mesophiles, the AR was most prevalent transiently at the investigated intermediate sampling point ( $48 \mathrm{~h}$ storage), at a stage where "total" counts are below or around $10^{5} \mathrm{CFU} / \mathrm{mL}$ where the milk is still acceptable for industrial dairy processes.

\section{Abbreviations}

AB: Antibiotic

AR: Antibiotic resistance

G: Gentamicin

C: Ceftazidim

L: Levofloxacin

TS: Trimethoprim-sulfamethoxazole.

\section{Acknowledgments}

The authors thank B.s. Sc Jyri Rekonen, for providing raw milk samples. They gratefully acknowledge all valuable comments and suggestions from Professor Julian Davies (University of British Columbia, Canada) and Professor Kathryn J. Boor and colleagues (Cornell University, USA). 


\section{References}

[1] European Union council regulation 92/46/EEC, "Overview of microbiological criteria for food stuffs in community legislation in force," June 2001.

[2] M. A. Cousin, "Presence and activity of psychrotrophic microorganisms in milk and dairy products: a review," Journal of Food Protection, vol. 45, pp. 172-207, 1982.

[3] M. C. Hayes and K. J. Boor, "Raw milk and fluid milk products," in Applied Dairy Microbiology, E. H. Marth and J. L. Steele, Eds., pp. 59-76, Marcel Dekker, New York, NY, USA, 2nd edition, 2001.

[4] J. V. Chambers, "The microbiology of raw milk," in Dairy Microbiology Handbook, R. K. Robinson, Ed., pp. 39-89, Wiley, New York, NY, USA, 3rd edition, 2002.

[5] J. D. McPhee and M. W. Griffiths, "Psychrotrophic bacteria, Pseudomonas spp.," in Encyclopedia of Dairy Sciences, $\mathrm{H}$. Roginski, J. W. Fuquay, and P. Fox, Eds., vol. 4, pp. 2340-2351, Academic Press, New York, NY, USA, 2002.

[6] J. M. Jay, M. J. Loessner, and D. A. Golden, "Protection of foods with low-temperatures, and characteristics of psychrotrophic microorganism," in Modern Food Microbiology, J. M. Jay, M. J. Loessner, and D. A. Golden, Eds., pp. 395-409, Springer, New York, NY, USA, 7th edition, 2005.

[7] J. L. Schoeni and A. C. Lee Wong, "Bacillus cereus food poisoning and its toxins," Journal of Food Protection, vol. 68, no. 3, pp. 636-648, 2005.

[8] M. J. Gray, N. E. Freitag, and K. J. Boor, "How the bacterial pathogen Listeria monocytogenes mediates the switch from environmental Dr. Jekyll to pathogenic Mr. Hyde," Infection and Immunity, vol. 74, no. 5, pp. 2506-2512, 2006.

[9] J. E. McGowan, "Resistance in nonfermenting gram-negative bacteria: multidrug resistance to the maximum," American Journal of Infection Control, vol. 34, no. 5, pp. S29-S37, 2006.

[10] M. A. Fischbach and C. T. Walsh, "Antibiotics for emerging pathogens," Science, vol. 325, no. 5944, pp. 1089-1093, 2009.

[11] F. M. Aarestrup, H. C. Wegener, and P. Collignon, "Resistance in bacteria of the food chain: epidemiology and control strategies," Expert Review of Anti-Infective Therapy, vol. 6, no. 5, pp. 733-750, 2008.

[12] P. Collignon, J. H. Powers, T. M. Chiller, A. Aidara-Kane, and F. M. Aarestrup, "World health organization ranking of antimicrobials according to their importance in human medicine: a critical step for developing risk management strategies for the use of antimicrobials in food production animals," Clinical Infectious Diseases, vol. 49, no. 1, pp. 132$141,2009$.

[13] M. Cassone and A. Giordano, "Resistance genes traveling the microbial internet: down the drain, up the food chain?" Expert Review of Anti-Infective Therapy, vol. 7, no. 6, pp. 637-639, 2009.

[14] J. Davies and D. Davies, "Origins and evolution of antibiotic resistance," Microbiology and Molecular Biology Reviews, vol. 74, no. 3, pp. 417-433, 2010.

[15] G. M. Durán and D. L. Marshall, "Ready-to-eat shrimp as an international vehicle of antibiotic-resistant bacteria," Journal of Food Protection, vol. 68, no. 11, pp. 2395-2401, 2005.

[16] H. H. Wang, M. Manuzon, M. Lehman et al., "Food commensal microbes as a potentially important avenue in transmitting antibiotic resistance genes," FEMS Microbiology Letters, vol. 254, no. 2, pp. 226-231, 2006.

[17] V. Perreten, F. Schwarz, L. Cresta, M. Boeglin, G. Dasen, and M. Teuber, "Antibiotic resistance spread in food," Nature, vol. 389, no. 6653, pp. 801-802, 1997.
[18] P. Lüthje and S. Schwarz, "Antimicrobial resistance of coagulase-negative staphylococci from bovine subclinical mastitis with particular reference to macrolide-lincosamide resistance phenotypes and genotypes," Journal of Antimicrobial Chemotherapy, vol. 57, no. 5, pp. 966-969, 2006.

[19] R. T. Garmo, S. Waage, S. Sviland, B. I. Henriksen, O. Østerås, and O. Reksen, "Reproductive performance, udder health, and antibiotic resistance in mastitis bacteria isolated from Norwegian Red cows in conventional and organic farming," Acta Veterinaria Scandinavica, vol. 52, article 11, 2010.

[20] R. A. M. Bombyk, A. L. Bykowski, C. E. Draper, E. J. Savelkoul, L. R. Sullivan, and T. J. O. Wyckoff, "Comparison of types and antimicrobial susceptibility of Staphylococcus from conventional and organic dairies in west-central Minnesota, USA," Journal of Applied Microbiology, vol. 104, no. 6, pp. 1726-1731, 2008.

[21] B. Wilhelm, A. Rajić, L. Waddell et al., "Prevalence of zoonotic or potentially zoonotic bacteria, antimicrobial resistance, and somatic cell counts in organic dairy production: current knowledge and research gaps," Foodborne Pathogens and Disease, vol. 6, no. 5, pp. 525-539, 2009.

[22] B. A. Straley, S. C. Donaldson, N. V. Hedge et al., "Public health significance of antimicrobial-resistant gram-negative bacteria in raw bulk tank milk," Foodborne Pathogens and Disease, vol. 3, no. 3, pp. 222-233, 2006.

[23] H. M. Nam, S. K. Lim, J. M. Kim, Y. S. Joo, K. C. Jang, and S. C. Jung, "In vitro activities of antimicrobials against six important species of gram-negative bacteria isolated from raw milk samples in Korea," Foodborne Pathogens and Disease, vol. 7, no. 2, pp. 221-224, 2010.

[24] P. Munsch-Alatossava and T. Alatossava, "Phenotypic characterization of raw milk-associated psychrotrophic bacteria," Microbiological Research, vol. 161, no. 4, pp. 334-346, 2006.

[25] P. Munsch-Alatossava and T. Alatossava, "Antibiotic resistance of raw-milk-associated psychrotrophic bacteria," Microbiological Research, vol. 162, no. 2, pp. 115-123, 2007.

[26] P. Munsch-Alatossava, O. Gursoy, and T. Alatossava, "Potential of nitrogen gas $\left(\mathrm{N}_{2}\right)$ to control psychrotrophs and mesophiles in raw milk," Microbiological Research, vol. 165, no. 2, pp. 122132,2010

[27] European Committee for antimicrobial susceptibility testing (EUCAST), "Determination of minimum inhibitory concentrations (MICs) of antibacterial agents by agar dilution," Clinical Microbiology and Infection, vol. 6, pp. 509-515, 2000.

[28] P. Munsch-Alatossava, V. Ikonen, T. Alatossava, and J. P. Gauchi, "Trends in antibiotic resistance (AR) in mesophilic and psychrotrophic bacterial populations during cold storage of raw milk, produced by organic and conventional farming systems," Antibiotic Resistance. In press.

[29] WJ Conover, Practical Non Parametrics Statistics, John Wiley and Sons, New York, NY, USA, 2nd edition, 1980.

[30] Finnish association for milk hygiene, 2008, http://www.maitohygienialiitto.fi.

[31] Finnish Food safety authority, 2008, http://www.evira.fi.

[32] K. Thomson, M. Rantala, M. Hautala, S. Pyörälä, and L. Kaartinen, "Cross-sectional prospective survey to study indicationbased usage of antimicrobials in animals: results of use in cattle," BMC Veterinary Research, vol. 4, article no. 15, 2008.

[33] T. Lehtolainen, A. Shwimmer, N. Y. Shpigel, T. HonkanenBuzalski, and S. Pyörälä, "In vitro antimicrobial susceptibility of Escherichia coli isolates from clinical bovine mastitis in Finland and Israel," Journal of Dairy Science, vol. 86, no. 12, pp. 3927-3932, 2003. 
[34] C. Greko et al., "Reflection paper on the use of third and fourth generation cephalosporins in food producing animals in the European Union: development of resistance and impact on human and animal health," Journal of Veterinary Pharmacology and Therapeutics, vol. 32, no. 6, pp. 515-533, 2009.

[35] S. C. Nickerson, "Mastitis pathogens/Contagious pathogens," in Encyclopedia of Dairy Sciences, H. Roginski, J. W. Fuquay, and P. Fox, Eds., vol. 3, pp. 1723-1734, Academic Press, New York, NY, USA, 2002.

[36] P. Courvalin, "Transfer of antibiotic resistance genes between gram-positive and gram-negative bacteria," Antimicrobial Agents and Chemotherapy, vol. 38, no. 7, pp. 1447-1451, 1994.

[37] B. M. Marshall, D. J. Ochieng, and S. B. Levy, "Commensals: underappreciated reservoir of antibiotic resistance," Microbe, vol. 4, no. 5, pp. 231-238, 2009.

[38] A. L. Koch, "Oligotrophs versus copiotrophs," BioEssays, vol. 23 , no. 7, pp. 657-661, 2001.

[39] N. Fierer, M. A. Bradford, and R. B. Jackson, "Toward an ecological classification of soil bacteria," Ecology, vol. 88, no. 6, pp. 1354-1364, 2007.

[40] N. A. Séveno, D. Kallifidas, K. Smalla et al., "Occurrence and reservoirs of antibiotic resistance genes in the environment," Reviews in Medical Microbiology, vol. 13, no. 1, pp. 15-27, 2002.

[41] M. G. Brown and D. L. Balkwill, "Antibiotic resistance in bacteria isolated from the deep terrestrial subsurface," Microbial Ecology, vol. 57, no. 3, pp. 484-493, 2009.

[42] D. I. Andersson, "The biological cost of mutational antibiotic resistance: any practical conclusions?" Current Opinion in Microbiology, vol. 9, no. 5, pp. 461-465, 2006.

[43] H. K. Allen, J. Donato, H. H. Wang, K. A. Cloud-Hansen, J. Davies, and J. Handelsman, "Call of the wild: antibiotic resistance genes in natural environments," Nature Reviews Microbiology, vol. 8, no. 4, pp. 251-259, 2010. 

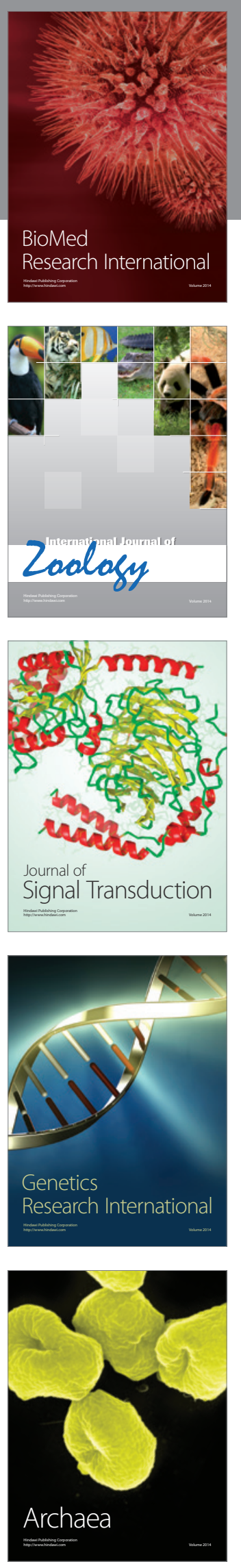
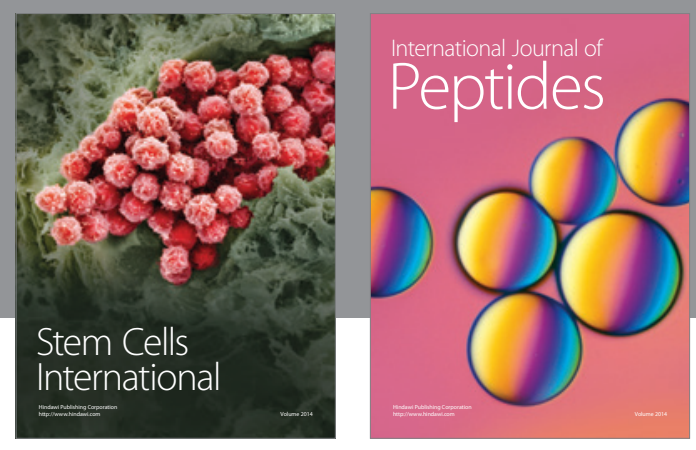

Submit your manuscripts at

http://www.hindawi.com
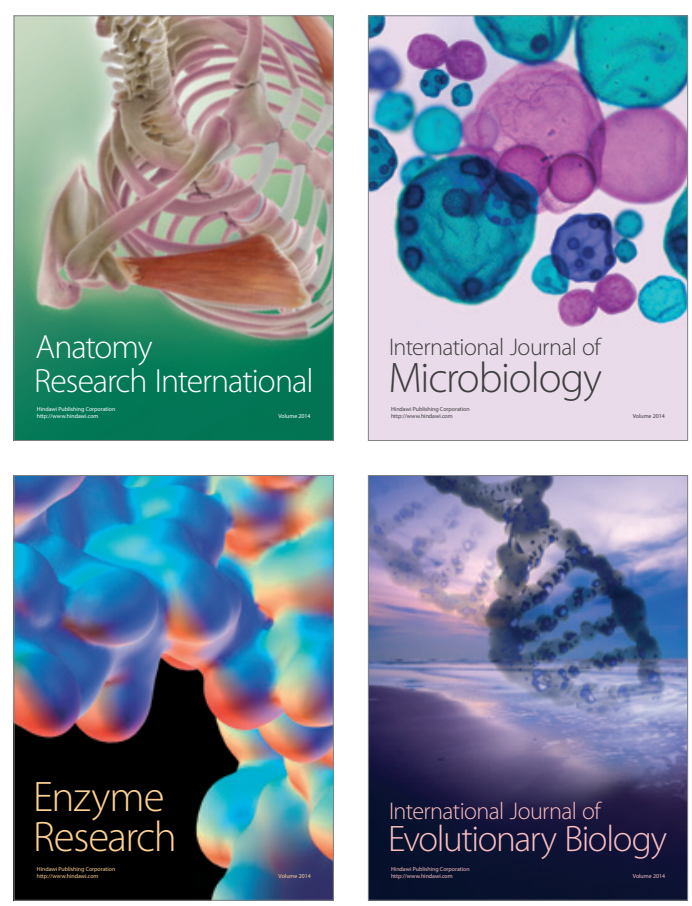
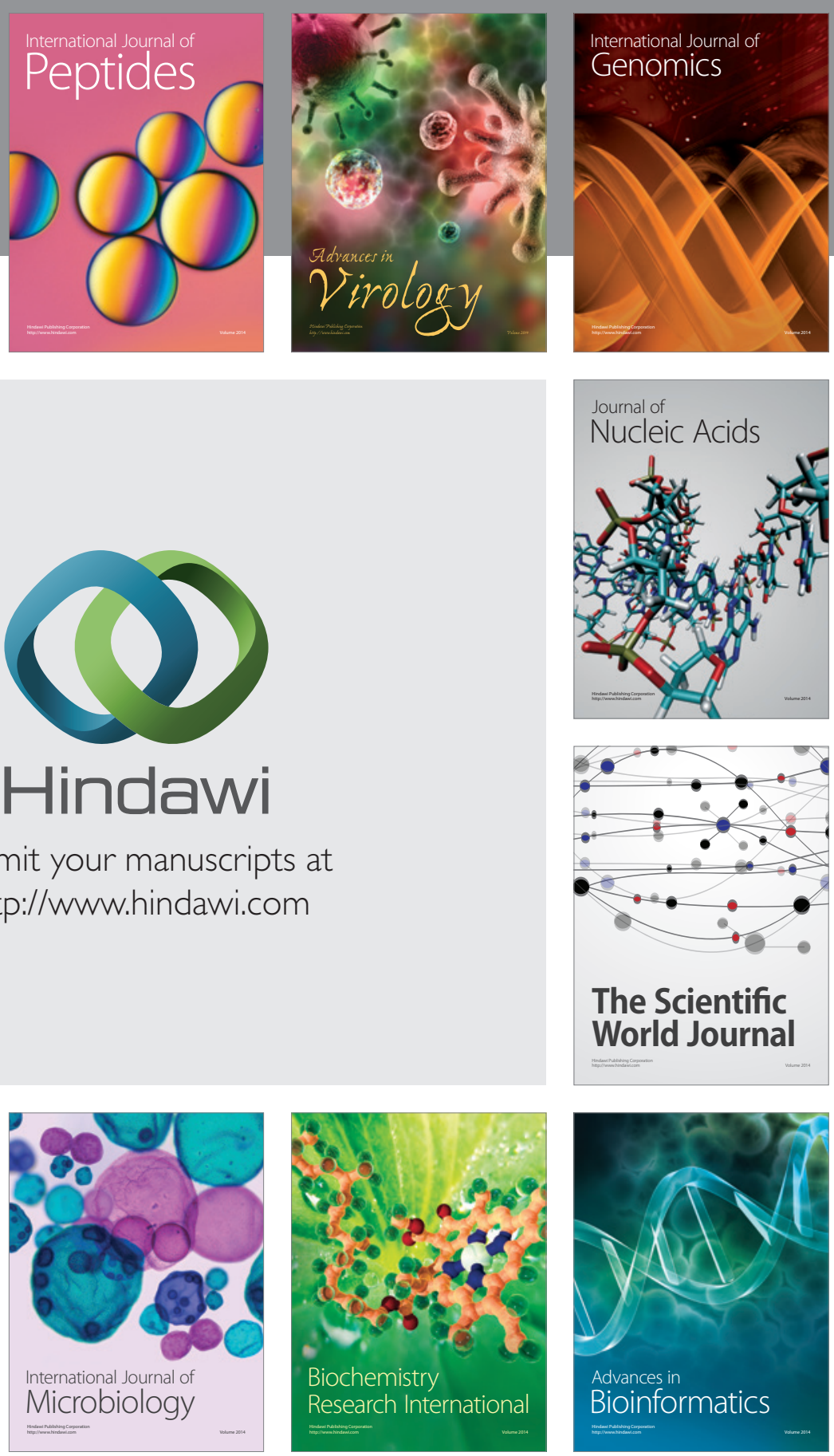

The Scientific World Journal
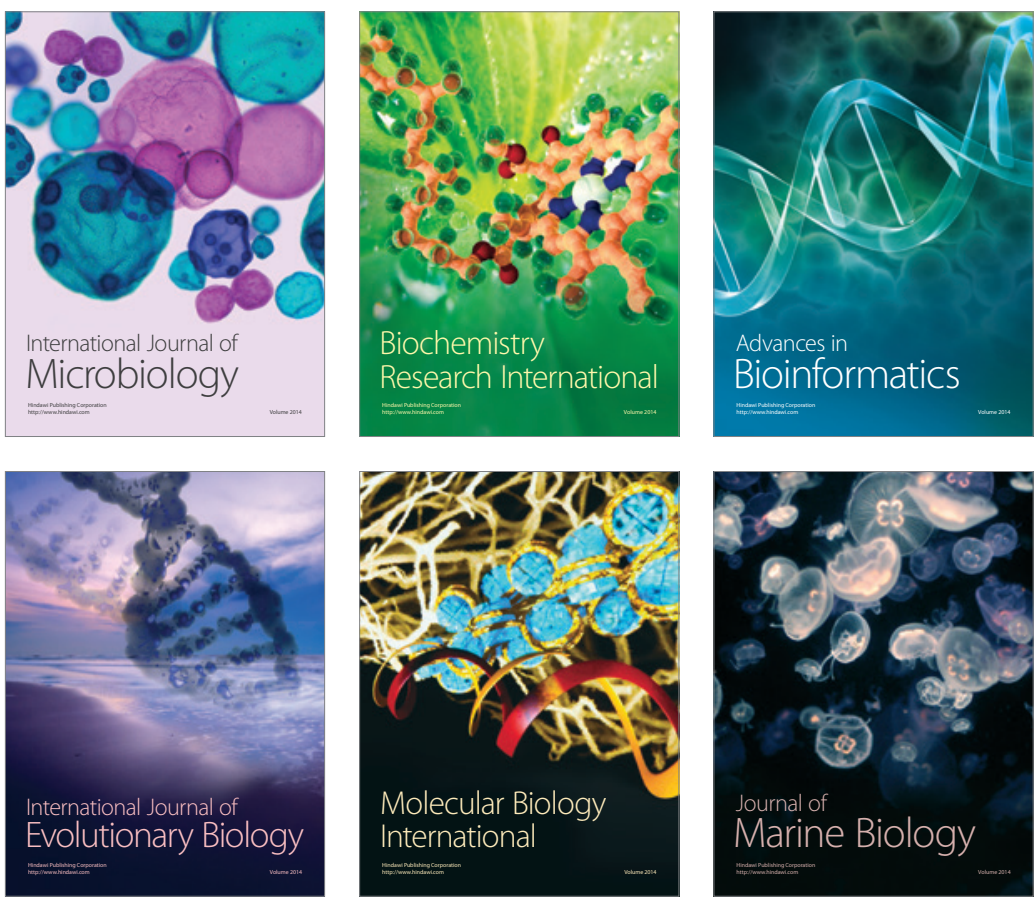